\title{
Hand and ultrasonic instrumentation in the treatment of chronic periodontitis after supragingival plaque control
}

\author{
Instrumentação manual e ultra-sônica no tratamento da \\ periodontite crônica após controle de placa supragengival
}

\author{
Ana Chapper* \\ Viviane Vasconcelos Catão** \\ Rui Vicente Oppermann***
}

\begin{abstract}
This study compared the clinical effects of hand or ultrasonic scaling and root planing on the treatment of chronic periodontitis. After supragingival plaque control, twenty patients were examined by a blinded and calibrated examiner for probing pocket depth (PPD), clinical attachment level (CAL) and bleeding on probing (BOP). Experimental teeth were allocated to the following subgingival treatment groups according to PPD: 1) hand instrumentation; 2) hand instrumentation with irrigation; 3) ultrasonic instrumentation; 4) ultrasonic followed by hand instrumentation. Time used in the procedures was recorded. Follow-up examinations were performed at 30 and 90 days after treatment. Each patient's individual BOP, PPD and CAL means were analyzed with repeated-measures ANOVA. Differences in the instrumentation time were analyzed with 1-way ANOVA. Significance level was established at $5 \%$. All treatments produced significant changes in the clinical parameters. BOP reduced, in proximal surfaces, from $67.21-79.17 \%$ at baseline to $45.75-51.54 \%$ at 90 days. Significant reductions were also found for PPD and CAL in all groups, both in proximal and free surfaces. Reductions in mean PPD at 90 days ranged from 0.92 to $1.14 \mathrm{~mm}$ for the free surfaces and from 1.01 to $1.35 \mathrm{~mm}$ for proximal surfaces, whereas reductions in CAL ranged from 0.43 to $0.82 \mathrm{~mm}$ and from 0.60 to $0.73 \mathrm{~mm}$ for free and proximal surfaces, respectively. Mean instrumentation time ranged from 4.77 to 5.30 minutes. No statistically significant differences were found among the four study groups. It can be concluded that the four methods of subgingival instrumentation were equally efficacious in the improvement of the studied clinical parameters.
\end{abstract}

DESCRIPTORS: Periodontitis, therapy; Dental scaling; Dental plaque, prevention \& control; Ultrasonics; Root planing.

\begin{abstract}
RESUMO: Este estudo comparou, clinicamente, o efeito de raspagem e alisamento radicular por instrumentações manual e ultra-sônica no tratamento da periodontite crônica, após o controle de placa supragengival em 20 pacientes. Os parâmetros clínicos profundidade de sondagem (PS), nível de inserção clínica (NIC) e sangramento à sondagem (SS) foram avaliados por um examinador calibrado e cego. Os dentes experimentais foram alocados para uma das seguintes abordagens subgengivais, de acordo com a profundidade de sondagem: 1) manual, 2) manual associada à irrigação, 3) ultra-sônica, 4) ultra-sônica previamente à manual. O tempo usado nos procedimentos foi registrado. Avaliações foram feitas 30 e 90 dias após os tratamentos. Médias individuais de SS, PS e NIC foram analisadas pelo teste ANOVA de medidas repetidas $(\mathrm{p}<0,05)$. Diferenças no tempo de instrumentação foram analisadas por meio do teste ANOVA para um critério de classificação $(p<0,05)$. Os resultados revelaram que os tratamentos produziram alterações significativas nos parâmetros clínicos sem diferenças estatisticamente significantes entre os quatro grupos. Observaram-se reduções no SS, que, nas faces proximais, variou de 67,21 a $79,17 \%$, no início, para 45,75 a 51,54\% no final. Também foram observadas reduções significativas na PS e no NIC em todos os grupos, tanto para faces livres quanto proximais: as médias da PS aos 90 dias reduziram entre 0,92 e $1,14 \mathrm{~mm}$ nas faces livres e entre 1,01 e $1,35 \mathrm{~mm}$ nas proximais, enquanto para NIC as reduções foram de $0,43 \mathrm{a}$ $0,82 \mathrm{~mm}$ e 0,60 a 0,73 mm, para as faces livres e proximais respectivamente. A média do tempo operatório variou de 4,77 a 5,30 minutos. Pôde-se concluir que as quatro modalidades terapêuticas de instrumentação subgengival foram igualmente eficazes na melhora dos parâmetros clínicos estudados.
\end{abstract}

DESCRITORES: Periodontite, terapia; Raspagem subgengival; Placa dentária, prevenção \& controle; Ultra-som; Aplainamento radicular.

\footnotetext{
* Master in Periodontology.

** Professor, Discipline of Periodontics, Gama Filho University.

*** Professor, Master's Degree Program in Periodontology, Lutheran University of Brazil.
} 
Chapper A, Catão VV, Oppermann RV. Hand and ultrasonic instrumentation in the treatment of chronic periodontitis after supragingival plaque control. Braz Oral Res 2005;19(1):41-6.

\section{INTRODUCTION}

Different methodologies have been used to compare the effects of hand and ultrasonic instrumentation. In vitro studies have shown that hand instrumentation tends to result in smoother root surfaces than ultrasonic instrumentation. However, remaining calculi and plaque have been found on the roots of teeth in studies conducted with either method ${ }^{12,13,17}$. Although these are important findings, in vitro studies are limited due to the need to extract the instrumented tooth for posterior analysis. The differences between in vitro and in vivo conditions make it difficult to interpret the clinical significance of such results. Moreover, the importance of a smooth root surface for successful healing has been questioned ${ }^{11,16}$.

Clinical studies have not demonstrated significant differences between the two subgingival instrumentation methods discussed here ${ }^{1,2,14}$. However, the results of these studies might have been affected by a therapeutic model that sees scaling and root planing as a basic procedure in the preparation for a surgical approach considered as the definitive treatment. In addition, although hand instrumentation has traditionally been used to scale the subgingival biofilm and calculus off the pathologically exposed root surface, greater emphasis has been given to nonsurgical subgingival scaling therapy performed with machine-driven instruments ${ }^{5,15}$.

For the treatment of periodontitis, procedures aiming at the subgingival dental area should be performed only when clinical signs of inflammation associated with the presence of supragingival plaque are previously controlled. Most of the studies comparing manual and ultrasonic instrumentation have not made such consideration and this may cause bias due to non controlled determinants such as established gingivitis ${ }^{8}$.

Therefore, the purpose of this study was to compare the clinical effect of subgingival scaling and root planing performed with hand and ultrasonic instruments in the treatment of chronic periodontitis in patients showing adequate supragingival plaque control.

\section{MATERIALS AND METHODS}

\section{Patients}

Participants in this study were selected from a group of patients referred to the program of Periodontology, School of Dentistry, ULBRA (Lutheran
University of Brazil) for periodontal treatment. Inclusion criteria were: a) patients with chronic periodontitis aged 35 years or older; b) patients with at least four single-rooted teeth with one or more sites showing pocket probing depth $\geq 6 \mathrm{~mm}$ and periodontal bleeding after supragingival plaque control, c) patients who consented in participating in the study by signing an informed consent form for minimal risk procedures in adults, d) clinical and radiographic examination should demonstrate that selected teeth were free of endoperiodontal lesions. Patients with systemic diseases, cardiac pacemakers or hormonal disorders were excluded, as well as patients that had made use of antimicrobial drugs in the preceding six months or that were taking immunosuppressive drugs. According to these criteria, 20 patients (13 males) were selected, with a median age of 42.50 years (38.50-47.75).

This study is in accordance with Resolution 196/96 of the Brazilian National Health Committee (Conselho Nacional de Saúde) and its amendments, and with the Helsinki Declaration of 1975 as revised in 1983. This study was approved by the Ethics Committee of the Lutheran University of Brazil (protocol 2003-147H), and all patients signed an informed consent form to participate in the study.

\section{Examination parameters}

- Calibration procedures: The patients were examined by only one blinded and calibrated examiner. The following clinical parameters were recorded: pocket probing depth (PPD), clinical attachment level (CAL) and bleeding on probing (BOP). Two examinations with a one week interval were performed. The results showed agreement for PPD and CAL measurements of $94.01 \%$ and $89.08 \%$, considering a difference of up to $1 \mathrm{~mm}$ between examinations.

- Clinical evaluation: Recordings were performed only in the single rooted teeth, although periodontal treatment included multirooted teeth as well. Clinical examinations were performed before the experimental period, and at 30 and 90 days. Efficiency was assessed by recording the mean time (in minutes) needed to treat each tooth with the aid of a chronometer.

\section{Experimental procedures}

The experimental treatments started immediately following supragingival plaque control by means of supragingival scaling and individual oral 
Chapper A, Catão VV, Oppermann RV. Hand and ultrasonic instrumentation in the treatment of chronic periodontitis after supragingival plaque control. Braz Oral Res 2005;19(1):41-6.

hygiene instructions. The single-rooted teeth selected in each patient were distributed into groups to be treated, according to PPD, with one of the following types of subgingival instrumentation: hand instrumentation $(\mathrm{H})$; hand instrumentation and subgingival irrigation with distilled water $(\mathrm{H}+\mathrm{I})$; ultrasonic instrumentation (U); ultrasonic instrumentation followed by hand instrumentation $(\mathrm{U}+\mathrm{H})$. Teeth allocation to the different groups followed a systematic distribution pattern in such way that all patients underwent all types of treatment in a number of teeth as similar as possible. A total of 293 teeth were included in the study.

Hand instrumentation consisted of subgingival scaling and root planing with Hirschfeld files (Newmar, São Paulo, Brazil) and Gracey curettes (Newmar, São Paulo, Brazil) according to the operator's criteria. Ultrasonic instrumentation was performed with an ultrasonic scaler with a piezoceramic transducer (Profi I Ceramic ${ }^{\circledR}$, Dabi Atlante SA - Indústrias Médico Odontológicas, São Paulo, Brazil). All clinical procedures were performed under local anesthesia (2\% lidocaine hydrochloride + norepinephrine, Probem, Manaus, Brazil) by only one trained operator. After each subgingival instrumentation session, patients received professional supragingival plaque removal and home care was reinforced.

Treatment was completed in a maximum of four weekly sessions. Patient plaque control was monitored and reinforced during follow-up examinations, but no professional cleaning was performed.

\section{Statistical analysis}

The patient was used as the unit of analysis. Each patient's individual BOP, PPD and CAL means were analyzed with repeated-measures ANOVA. Differences in the instrumentation time were analyzed with 1-way ANOVA. Significance level was established at 5\%.

\section{RESULTS}

Significant reductions in the BOP between baseline and post-treatment measurements were observed for all experimental groups (Table 1). In the free surfaces, baseline mean values ranged from $43.92 \%$ to $46.96 \%$, and were reduced to values from $16.62 \%$ to $23.83 \%$ at 90 days. The values for bleeding on probing in the proximal surfaces ranged from $67.21 \%$ to $79.17 \%$ at baseline. Signifi- cant reductions were already present at 30 days and after 90 days values ranged from $45.75 \%$ to $51.54 \%$. No statistically significant differences between treatments were observed.

The PPD mean in the free surfaces ranged from 2.60 to $2.85 \mathrm{~mm}$. Significant reductions were found already at 30 days (Table 2). At 90 days, PPD values ranged from 1.64 to $1.85 \mathrm{~mm}$ and were significantly lower than baseline values, but similar to the values observed after 30 days. A similar pattern was observed for the proximal surfaces. Mean PPD values found for the different groups were not significantly different when compared at different time points.

Table 3 shows that CAL means were also lower at 30 and 90 days for both free and proximal surfaces. Mean CAL values for the free surfaces ranged from 3.40 to $3.65 \mathrm{~mm}$. Reductions were already found at 30 days. At 90 days, CAL values were significantly lower than baseline values, ranging from 2.80 to $2.97 \mathrm{~mm}$. A similar result was observed for the proximal surfaces. No statistically significant differences were found among the four groups at different time points.

Mean instrumentation time for each tooth (Table 4) ranged from 4.77 to 5.30 minutes. No statistically significant differences were found in instrumentation time among the four study groups.

\section{DISCUSSION}

The results of the present study showed that hand and ultrasonic treatments determined significant changes in the clinical parameters related to chronic periodontitis. Moreover, no statistical differences between treatment modalities could be observed.

PPD measured after supragingival plaque control was established as an inclusion criterion. In fact, 8 patients were excluded due to pocket reductions related to the supragingival plaque control. Similar results have been reported by Fernandes et al. $^{8}$ (1989) and Catão ${ }^{3}$ (1999). Their studies showed that important changes in subgingival parameters such as PPD and BOP occur associated with the reduction of inflammation in the marginal gingiva following supragingival plaque control.

Bleeding scores were significantly reduced for all groups though the values for bleeding on probing in the proximal surfaces after 90 days ranged from $45.75 \%$ to $51.54 \%$. It is still open to question whether bleeding on probing as the only sign of residual disease justifies immediate re-treatment. 
Chapper A, Catão VV, Oppermann RV. Hand and ultrasonic instrumentation in the treatment of chronic periodontitis after supragingival plaque control. Braz Oral Res 2005;19(1):41-6.

TABLE 1 - Means and standard deviations for periodontal bleeding on probing (\%) on free and proximal surfaces at baseline, 30 and 90 days.

\begin{tabular}{|c|c|c|c|c|c|}
\hline \multirow{2}{*}{\multicolumn{2}{|c|}{ Groups }} & \multirow{2}{*}{$\mathrm{n}$} & \multirow{2}{*}{ Baseline } & \multicolumn{2}{|c|}{ Post-treatment } \\
\hline & & & & 30 days & 90 days \\
\hline \multirow{4}{*}{ 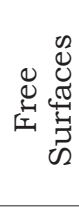 } & Hand instrumentation & 20 & $46.96 \pm 13.09$ Аа & $23.96 \pm 13.84 \mathrm{Ab}$ & $16.62 \pm 12.74 \mathrm{Ab}$ \\
\hline & Hand instrumentation + irrigation & 20 & $46.87 \pm 20.69$ Аа & $25.21 \pm 12.82^{\mathrm{Ab}}$ & $20.42 \pm 18.32 \mathrm{Ab}$ \\
\hline & Ultrasonic instrumentation & 20 & $44.29 \pm 21.87$ Аа & $29.54 \pm 17.85^{\mathrm{Ab}}$ & $23.83 \pm 17.24 \mathrm{Ab}$ \\
\hline & Ultrasonic + hand instrumentation & 20 & $43.92 \pm 13.95 \mathrm{Aa}$ & $24.21 \pm 13.94 \mathrm{Ab}$ & $18.04 \pm 14.15^{\mathrm{Ab}}$ \\
\hline \multirow{4}{*}{ 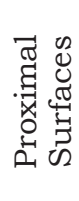 } & Hand instrumentation & 20 & $70.46 \pm 14.32$ Аа & $57.62 \pm 17.49 \mathrm{Ab}$ & $45.75 \pm 21.98 \mathrm{Ab}$ \\
\hline & Hand instrumentation + irrigation & 20 & $67.21 \pm 21.14^{\mathrm{Aa}}$ & $57.04 \pm 23.74$ Aab & $50.75 \pm 19.35^{\mathrm{Ab}}$ \\
\hline & Ultrasonic instrumentation & 20 & $75.79 \pm 19.25$ Аа & $58.21 \pm 21.65^{\mathrm{Ab}}$ & $51.54 \pm 25.79 \mathrm{Ab}$ \\
\hline & Ultrasonic + hand instrumentation & 20 & $79.17 \pm 12.24 \mathrm{Aa}$ & $55.83 \pm 19.53 \mathrm{Ab}$ & $48.92 \pm 23.52 \mathrm{Ab}$ \\
\hline
\end{tabular}

Results followed by the same uppercase letter in the column do not differ statistically ( $>>0.05)$. Results followed by the same lowercase letter in the line do not differ statistically $(\mathrm{p}>0.05)$.

TABLE 2 - Means and standard deviations $(\mathrm{mm})$ for pocket probing depth in free and proximal surfaces at baseline, 30 and 90 days.

\begin{tabular}{|c|c|c|c|c|c|}
\hline \multirow{2}{*}{\multicolumn{2}{|c|}{ Groups }} & \multirow{3}{*}{$\begin{array}{c}\mathrm{n} \\
20\end{array}$} & \multirow{3}{*}{$\begin{array}{c}\text { Baseline } \\
2.71 \pm 0.73^{\mathrm{Aa}}\end{array}$} & \multicolumn{2}{|c|}{ Post-treatment } \\
\hline & & & & \multirow{2}{*}{$\frac{30 \text { days }}{2.06 \pm 0.64{ }^{\mathrm{Ab}}}$} & \multirow{2}{*}{$\begin{array}{c}90 \text { days } \\
1.79 \pm 0.59 \mathrm{Ab}\end{array}$} \\
\hline \multirow{4}{*}{ 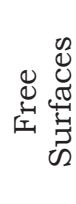 } & Hand instrumentation & & & & \\
\hline & Hand instrumentation + irrigation & 20 & $2.79 \pm 0.83$ Аа & $1.85 \pm 0.53 \mathrm{Ab}$ & $1.65 \pm 0.50 \mathrm{Ab}$ \\
\hline & Ultrasonic instrumentation & 20 & $2.85 \pm 1.06 \mathrm{Aa}$ & $2.05 \pm 0.75^{\mathrm{Ab}}$ & $1.85 \pm 0.58 \mathrm{Ab}$ \\
\hline & Ultrasonic + hand instrumentation & 20 & $2.60 \pm 0.58 \mathrm{Aa}$ & $1.82 \pm 0.46^{\mathrm{Ab}}$ & $1.64 \pm 0.36^{\mathrm{Ab}}$ \\
\hline \multirow{4}{*}{  } & Hand instrumentation & 20 & $4.56 \pm 0.83 \mathrm{Aa}$ & $3.43 \pm 0.58 \mathrm{Ab}$ & $3.55 \pm 1.14 \mathrm{Ab}$ \\
\hline & Hand instrumentation + irrigation & 20 & $4.33 \pm 1.00 \mathrm{Aa}$ & $3.14 \pm 0.64 \mathrm{Ab}$ & $3.18 \pm 0.61 \mathrm{Ab}$ \\
\hline & Ultrasonic instrumentation & 20 & $4.47 \pm 0.89 \mathrm{Aa}$ & $3.51 \pm 0.73^{\mathrm{Ab}}$ & $3.21 \pm 0.83^{\mathrm{Ab}}$ \\
\hline & Ultrasonic + hand instrumentation & 20 & $4.58 \pm 0.97 \mathrm{Aa}$ & $3.36 \pm 0.63^{\mathrm{Ab}}$ & $3.23 \pm 0.63 \mathrm{Ab}$ \\
\hline
\end{tabular}

Results followed by the same uppercase letter in the column do not differ statistically ( $p>0.05$ ). Results followed by the same lowercase letter in the line do not differ statistically $(\mathrm{p}>0.05)$.

TABLE 3 - Means and standard deviations $(\mathrm{mm})$ of clinical attachment level in free and proximal surfaces at baseline, 30 and 90 days.

\begin{tabular}{|c|c|c|c|c|c|}
\hline \multirow{2}{*}{\multicolumn{2}{|c|}{ Groups }} & \multirow{3}{*}{$\begin{array}{c}n \\
20\end{array}$} & \multirow{3}{*}{$\begin{array}{c}\text { Baseline } \\
3.65 \pm 1.09 \mathrm{Aa}\end{array}$} & \multicolumn{2}{|c|}{ Post-treatment } \\
\hline & & & & 30 days & 90 days \\
\hline \multirow{4}{*}{ 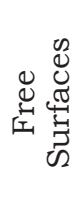 } & Hand instrumentation & & & $3.08 \pm 1.14^{\mathrm{Ab}}$ & $2.83 \pm 1.14^{\mathrm{Ab}}$ \\
\hline & Hand instrumentation + irrigation & 20 & $3.62 \pm 1.26 \mathrm{Aa}$ & $2.95 \pm 1.24 \mathrm{Ab}$ & $2.83 \pm 1.14^{\mathrm{Ab}}$ \\
\hline & Ultrasonic instrumentation & 20 & $3.40 \pm 1.59 \mathrm{Aa}$ & $3.16 \pm 1.52 \mathrm{Aab}$ & $2.97 \pm 1.29 \mathrm{Ab}$ \\
\hline & Ultrasonic + hand instrumentation & 20 & $3.46 \pm 1.07 \mathrm{Aa}$ & $2.97 \pm 1.15^{\mathrm{Ab}}$ & $2.80 \pm 1.08^{\mathrm{Ab}}$ \\
\hline \multirow{4}{*}{ 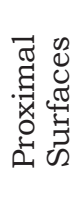 } & Hand instrumentation & 20 & $4.48 \pm 1.14^{\mathrm{Aa}}$ & $3.99 \pm 1.13^{\mathrm{Ab}}$ & $3.75 \pm 1.14^{\mathrm{Ab}}$ \\
\hline & Hand instrumentation + irrigation & 20 & $4.52 \pm 1.23^{\mathrm{Aa}}$ & $3.91 \pm 1.20^{\mathrm{Ab}}$ & $3.88 \pm 1.25^{\mathrm{Ab}}$ \\
\hline & Ultrasonic instrumentation & 20 & $4.59 \pm 1.58 \mathrm{Aa}$ & $4.14 \pm 1.57 \mathrm{Ab}$ & $3.99 \pm 1.52 \mathrm{Ab}$ \\
\hline & Ultrasonic + hand instrumentation & 20 & $4.72 \pm 1.35 \mathrm{Aa}$ & $4.15 \pm 1.38 \mathrm{Ab}$ & $4.01 \pm 1.36 \mathrm{Ab}$ \\
\hline
\end{tabular}

Results followed by the same uppercase letter in the column do not differ statistically ( $p>0.05$ ). Results followed by the same lowercase letter in the line do not differ statistically $(\mathrm{p}>0.05)$. 
Chapper A, Catão VV, Oppermann RV. Hand and ultrasonic instrumentation in the treatment of chronic periodontitis after supragingival plaque control. Braz Oral Res 2005;19(1):41-6.

TABLE 4 - Time needed for subgingival instrumentation of each tooth.

\begin{tabular}{l|c|c}
\hline \multicolumn{1}{c|}{ Groups } & $\mathrm{n}$ & $\begin{array}{c}\text { Mean } \pm \text { standard } \\
\text { deviation (min) }\end{array}$ \\
\hline Hand instrumentation & 20 & $4.98 \pm 1.82^{\mathrm{A}}$ \\
\hline $\begin{array}{l}\text { Hand instrumentation }+ \\
\text { irrigation }\end{array}$ & 20 & $4.77 \pm 1.96^{\mathrm{A}}$ \\
\hline Ultrasonic instrumentation & 20 & $5.30 \pm 2.38^{\mathrm{A}}$ \\
\hline $\begin{array}{l}\text { Ultrasonic }+ \\
\text { hand instrumentation }\end{array}$ & 20 & $4.82 \pm 1.73^{\mathrm{A}}$ \\
\hline \hline
\end{tabular}

Results followed by the same uppercase letter in the column do not differ statistically $(\mathrm{p}>0.05)$.

It has been shown that bleeding may occur in what appears to be clinically healthy conditions ${ }^{6}$. Conversely, at sites with apparent histological evidence of chronic inflammation, bleeding may not occur ${ }^{6}$. Thus, these BOP results do not indicate that the periodontal therapy was not effective. They suggest the need for short observational intervals to maintain an adequate supragingival plaque control. Poor plaque control may lead to gingival bleeding, which may become a misleading factor when assessing the eficacy of the periodontal therapy.

Pocket probing depths and loss of attachment were significantly reduced in all types of treatment. This confirmed previous findings reported in studies with different experimental conditions ${ }^{1,2,14}$. In fact, it is reasonable to expect that greater initial depths lead to greater reductions after treatment ${ }^{6}$. The changes in PPD and CAL, observed already at 30 days, were partially a consequence of the reduction in inflammation resulting from subgingival plaque removal. Changes in PPD and CAL are expected to occur as a consequence of edema reduction, increased tissue tonus, or formation of a long junctional epithelium ${ }^{7}$. The results of clinical studies suggest that a 3-month post-treatment interval is suitable for re-evaluation ${ }^{6}$. Most of the clinical healing has usually occurred at this time, even in areas with initial deep lesions ${ }^{1,2}$. In the present study, edema reduction was probably primarily related to the reduction of inflammation in the subgingival area, since the reduction of inflammation in the marginal area, which followed supragingival plaque control, had already occurred.

The findings reported in the present study are in agreement with the results reported in a number of similar studies ${ }^{15}$. In the present study, it was observed 90 days following instrumentations that the mean reduction of attachment loss ranged from 0.43 to $0.82 \mathrm{~mm}$ and from 0.60 to $0.73 \mathrm{~mm}$ for free and proximal surfaces, respectively. Badersten et al. ${ }^{1,2}(1981,1984)$ observed mean reduction of clinical attachment loss of $0.5 \mathrm{~mm}$ while Kocher et al. ${ }^{10}$ (1997) observed mean reduction of clinical attachment loss of $0.71 \pm 1.01 \mathrm{~mm}$ after a 6-month period of evaluation. However, in the present study, the results should be interpreted with caution. Single-rooted teeth in adult patients with chronic periodontitis without local or systemic complications are a convenient model and have often been used in other studies found in the literature ${ }^{1,2,4,9,13,14}$.

The time required to complete treatment has a direct effect on the cost-benefit ratio. In the present study, there was no statistical difference between therapies related to mean time to treat one tooth during therapy. This result differs from findings of other studies assessing both time needed for treatment and clinical outcome variables ${ }^{15}$. In the study of Badersten et al. ${ }^{2}$ (1984), the mean time needed to treat one tooth during initial therapy was 5.35 minutes using machine-driven instrumentation and 6.15 minutes using hand instrumentation. Torfason et al. ${ }^{14}$ (1979) took 2.10 minutes on average to treat one tooth using ultrasonic instruments and 2.40 minutes using hand instruments. In these studies, there was no difference in clinical benefit between ultrasonic and manual instrumentation though subgingival debridement was completed in less time with ultrasonic than with hand instruments. In the present study, besides calculus removal instrumentation, the operator aimed at a thorough root planing covering the entire root area affected. The desire to obtain a root surface as smooth as possible might have affected the results for instrumentation time.

\section{CONCLUSIONS}

1. All types of subgingival hand and ultrasonic instrumentation used in this study resulted in significant improvement in the clinical parameters.

2. Scaling and root planing manually or with the aid of ultrasonic instrument after supragingival plaque control yielded similar results, significantly reducing bleeding on probing, pocket probing depth and clinical attachment loss. Irrigation with distilled water had no effect on the results.

3. The mean time for instrumentation was similar for the different types of treatment. 
Chapper A, Catão VV, Oppermann RV. Hand and ultrasonic instrumentation in the treatment of chronic periodontitis after supragingival plaque control. Braz Oral Res 2005;19(1):41-6.

\section{REFERENCES}

1. Badersten A, Nilvéus R, Egelberg J. Effect of nonsurgical periodontal therapy. I. Moderately advanced periodontitis. J Clin Periodontol 1981;8:57-72.

2. Badersten A, Nilvéus R, Egelberg J. Effect of nonsurgical periodontal therapy. II. Severely advanced periodontitis. J Clin Periodontol 1984;11:63-76.

3. Catão VV. O efeito do controle de placa supragengival no diagnóstico clínico da doença periodontal [Dissertação de Mestrado]. Canoas: Universidade Luterana do Brasil; 1999.

4. Cercek JF, Kiger RD, Garrett S, Egelberg J. Relative effects of plaque control and instrumentation on the clinical parameters of human periodontal disease. J Clin Periodontol 1983;10:46-56.

5. Drisko $\mathrm{CH}$. Root instrumentation. Power-driven versus manual scalers, which one? Dent Clin North Am 1998;42:229-44.

6. Egelberg J, Claffey N. Periodontal re-evaluation. The scientific way. Copenhagen: Munksgaard; 1994.

7. Fernandes MI. Avaliação histológica de raspagem e alisamento radiculares subgengivais [Dissertação de Mestrado]. Porto Alegre: Universidade Federal do Rio Grande do Sul; 1997.

8. Fernandes MI, Friedrich MEG, Oppermann RV. O efeito do controle da placa supragengival na doença periodontal. In: $6^{\mathrm{a}}$ Reunião Anual da SBPqO; 1989; São Paulo. Anais. São Paulo: Sociedade Brasileira de Pesquisa Odontológica; 1989. p. 107.

9. Haffajee A, Socransky S, Goodson J. Clinical parameters as predictors of destructive periodontal disease activity. J Clin Periodontol 1983;10:257-65.
10. Kocher T, Ruhling A, Momsen H, Plagmann HC. Effectiveness of subgingival instruments with power-driven instruments in the hands of experienced and inexperienced operators. A study on manikins. J Clin Periodontol 1997;24(7):498-504.

11. Oberholzer R, Rateitschak KH. Root cleaning or root smoothing - an in vivo study. J Clin Periodontol 1996;23(4):326-30.

12. Stende GW, Schaffer EM. A comparison of ultrasonic and hand scaling. J Periodontol 1961;32:312-4.

13. Thornton S, Garnick J. Comparison of ultrasonic to hand instruments in the removal of subgingival plaque. $J$ Periodontol 1982;53:35-7.

14. Torfason T, Kiger R, Selvig KA, Egelberg J. Clinical improvement of gingival conditions following ultrasonic versus hand instrumentation of periodontal pockets. J Clin Periodontol 1979;6:165-76.

15. Tunkel J, Heinecke A, Flemmig TF. A systematic review of efficacy of machine-driven and manual subgingival debridement in the treatment of chronic periodontitis. $J$ Clin Periodontol 2002:29 Suppl 3:72-81.

16. Waerhaug J. Microscopic demonstration of tissue reaction incident to removal of subgingival calculus. J Periodontol 1955;26:26-9.

17. Wilkinson RF, Maybury JE. Scanning electron microscopy of the root surface following instrumentation. J Periodontol 1973;44:559-63.

Received for publication on Nov 09, 2004

Sent for alterations on Feb 24, 2005

Accepted for publication on Mar 07, 2005 